\title{
Postnatal development of thermoregulation in laboratory mice
}

\author{
Kari Y. H. Lagerspetz \\ Zoophysiological Laboratory, Department of Zoology, \\ University of Turku, Turku, Finland
}

\begin{abstract}
KURZFASSUNG: Postnatale Entwicklung der Thermoregulation bei Laboratoriumsmäusen. Laboratoriumsmäuse sind bis zum 7. Tag nach der Geburt beinahe völlig poikilotherm. Diese Periode ist durch starke Kälteresistenz, beträchtliches relatives Gewicht und hohe Sukzinodehydrogenase-Aktivität des braunen Fettgewebes und Thermo-Orthokinese charakterisiert. Möglicherweise ist bereits die Nebennierenrinde an der noch schlecht entwickelten Thermoregulation funktionell beteiligt. Die Zunahme der Wärmeproduktion in der Zeit vom 7 . bis 15. Tag nach der Geburt führt zu Homoiothermie bei Außentemperaturen von $20^{\circ}$ bis $30^{\circ} \mathrm{C}$. Gleichzeitig nimmt die Sukzinodehydrogenase-Aktivität des Lebergewebes zu. Dieser Sachverhalt ist wahrscheinlich durch die Zunahme der Schilddrüsenaktivität bedingt, welche auch die Beeinflussung des Sauerstoff verbrauchs durch Adrenalin verursacht. Das Muskelzittern in der Kälte erreicht im Alter von 15 bis 17 Tagen die Werte der adulten Tiere. Die Catecholamine des Nebennierenmarks nehmen während des Wachstums allmählich zu. Wahrscheinlich sind die Bedingungen für die Thermoregulation durch das Nebennierenmark in Alter von etwa drei Wochen bereits entwickelt. Vergleichend physiologische Befunde an Goldhamstern und Lemmingen werden mitgeteilt. Die Ausbildung des Zentralnervensystems und die darauf folgende Aktivierung des Endokriniums sind wahrscheinlich die widhtigsten kausalen Faktoren in der Entwicklung der Thermogenese.
\end{abstract}

\section{INTRODUCTION}

Even the most complex cybernetic systems of the higher animals have developed from relatively simple beginnings in the course of both evolution and ontogeny. Hence, one approach to the analysis of complex regulation systems is to study their evolution using lower animals or to observe their ontogenetic development using the embryos and young of higher animals.

In many small homoiothermic animals the mechanisms of thermoregulation are known to develop after birth. The intention of the present paper is to review the results of studies concerning the postnatal development of thermoregulation in laboratory mice and in some other small mammals. To some extent, this paper also represents a short progress report of some recent research at this laboratory. 


\section{DEVELOPMENT OF HOMOIOTHERMY}

If newborn mice are exposed to different ambient temperatures $\left(T_{A}\right)$, their body temperature $\left(\mathrm{T}_{\mathrm{B}}\right)$ usually either falls or rises to approach the $\mathrm{T}_{\mathrm{A}}$ and gradually stabilizes at a level close to it. A graphic description of the development of homoiothermy can be obtained by plotting the stabilized $T_{B}$ values against $T_{A}$ for mice of different ages. Such a description is presented as Figure 1, the data of which are based

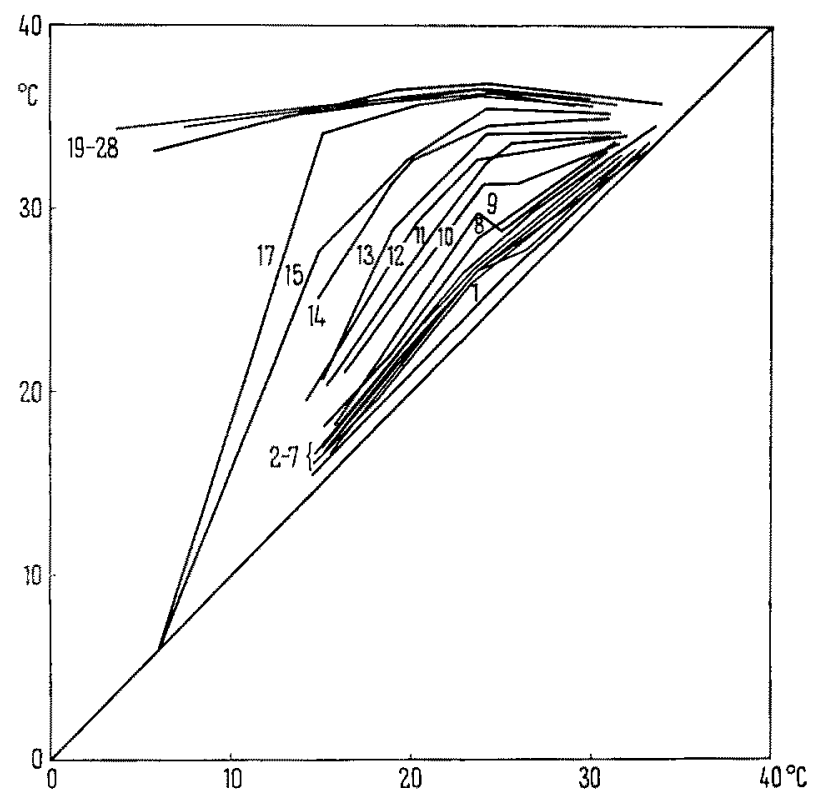

Fig. 1: Stabilized body temperature (vertical axis) of mice at different ages as a function of ambient temperature (horizontal axis). Age in days for each curve. (After LAgERspeTz 1962)

on $5900 T_{B}$ measurements (LAgerspetz 1962). On the basis of this diagram, the postnatal development of homoiothermy in the laboratory mice which we used (an albino stock bred in this laboratory for several years) can be divided roughly into three periods: (1) a period of apparent poikilothermy, which is nearly complete with only small deviations within a temperature range between $30^{\circ}$ and $20^{\circ} \mathrm{C}$ (between ages of 0 and 7 days); (2) a period of development of homoiothermy within that temperature range (between ages of 7 and 13 days); and (3) a period of development of homoiothermy typical for the adult animals, with the maintenance of the normal $T_{B}$ characteristic for adults (between 13 and 19 to 20 days).

In the following, the thermoregulatory mechanisms are discussed in their chronological order of appearance. It must be noted that in some cases the development entails the disappearance of some mechanism and its replacement with another one. In other cases the development seems to be more simple and gradual. 


\section{COLD RESISTANCE}

Two hundred young mice of different ages up to 27 days were subjected to cold environment $\left(T_{A}-10^{\circ} \mathrm{C}\right.$ ) for varying periods (LAGERSPETZ 1962). After their $T_{B}$ had attained the desired level, recovery of the animals was attempted simply by placing them again in a warm environment. It was found that mice aged less than 5 days could be recovered from much lower $T_{B}$ (about $O^{\circ} \mathrm{C}$ ) than older ones. The cold resistance seemed to undergo a development between the ages of 5 and 16 to 18 days. At the age of 18 days the mice survived a hypothermia with $T_{B}$ of about $9^{0} \mathrm{C}$, which also is the critical level for adults.

The results show that young mice which have poor thermoregulation withstand much lower $T_{B}$ s than older animals whose thermoregulation is more effective. The high cold resistance of newborn mice might be caused by the relative insensitivity of their immature central nervous system to hypoxia or to other changes which are caused by deep hypothermia. On the other hand, there might be such systems present in the newborn mice which effectively counteract the hypothermia at vital loci. The importance of the brown adipose tissue in the heat production of the young (DAwnins \& Hull 1964) must be taken into account in the interpretation of the high cold resistance in the newborn mice.

\section{BROWN FAT AND ADRENAL CORTEX}

DAwKINS \& HULL (1964) recently have shown the importance of multilocular adipose tissue or the so-called hibernating gland in the thermogenesis of newborn rabbits. Our studies have been concerned so far with the amount and the metabolic activity of brown fat in young mice. Brown or multilocular fat occurs at several places in the body of a mouse, the interscapular and dorsocervical fat pads being the largest masses of brown adipose tissue (SMITH 1963). Therefore, we carefully excised the brown fat from the dorsal neck and shoulder regions of young mice of various ages, weighed it and determined the succinic dehydrogenase complex activity of the tissue by a modification of the method of KUN \& ABOOD (1949) (LAgerspetz, TARKKONEN \& TIRRI 1962). The modification consisted in performing the reaction in vacuum in Thunberg tubes. This allowed the measurement of lower activities than the usual aerobic procedure.

The relative weight of the brown fat (in $\mathrm{mg}$ per $100 \mathrm{~g}$ body weight) and the succinic dehydrogenase activity of the brown fat in young mice of different ages are shown in Figure 2. It is based on the unpublished measurements performed by $\mathrm{Mr}$. H. TARKKONEN and Miss H. Julku. It appears that in mice the brown fat of the neck and shoulder regions reaches its maximum relative weight at birth and decreases in relative as well as in absolute weight during the first 4 to 5 days of postnatal life. A change in enzyme activity parallels this development. Later, the relative amount of brown fat remains constant while the enzyme activity in it increases again, reaching a maximum at the age of about 12 to 14 days. This maximum occurs at that time when the adult level of succinic dehydrogenase activity in the liver is attained (see below). 
It must be pointed out that the enzyme activity in brown fat is rather low when calculated per tissue weight, since most of the tissue mass consists of lipid material.

It is not known what stimulates brown fat to heat production in young animals, although catecholamines released by the sympathetic nervous system have been suggested to have this role in adults (BALL \& Jungas 1961).

The weight of the adrenal glands does not increase at least during the first three days after birth (LAGERSPETZ \& HisSA, unpublished). HaHN \& Koldovský (1958)

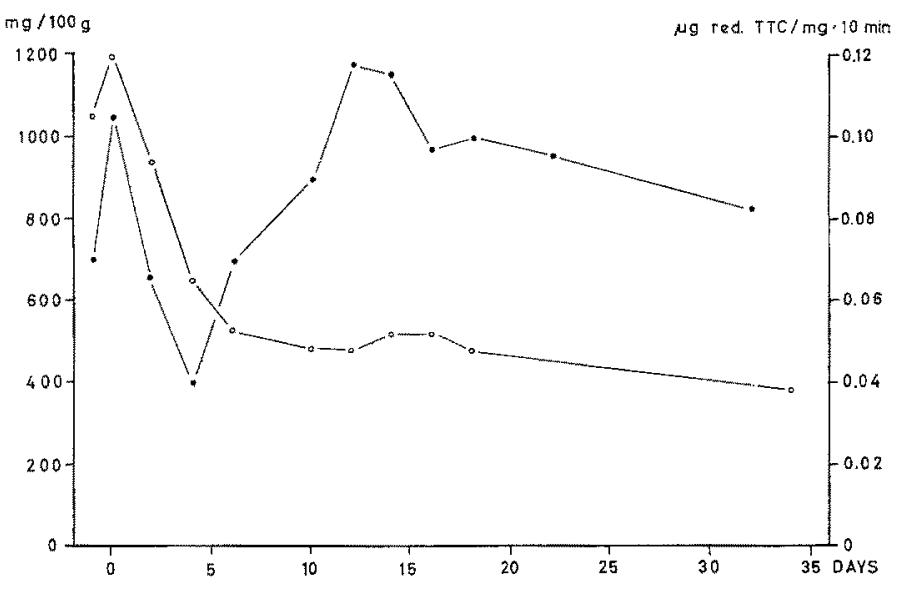

Fig. 2: Relative weight of interscapular and dorsocervical brown fat in milligrams per 100 grams of body weight (open circles: scale to left) and succinic dehydrogenase activity of the brown fat (dots: scale to right) in mice of different ages. (After TARKKONEN \& Julku, unpublished)

have shown that the $T_{B}$ of 5-day-old adrenalectomized rats is slightly lower at $T_{A}$ of $30^{\circ} \mathrm{C}$ than the $T_{B}$ of intact rats of the same age. The effect of adrenalectomy is counteracted by cortisone. Thus, it is possible that the adrenal cortex participates also in the poorly developed thermoregulation of newborn mice. However, in the experiments of $H_{A H N} \&$ Koldovskŕ, animals even after adrenalectomy had $T_{B}$ somewhat higher than $\mathrm{T}_{\mathrm{A}}$ at $30^{\circ} \mathrm{C}$. Thus, the adrenals were not indispensable for some thermoregulation to occur, and other mechanisms also seem to be involved. One possible mechanism is motor activity.

\section{MOTOR ACTIVITY}

It was shown by Pichotka $(1960,1964)$ and CASsin (1963) that the rate of oxygen consumption of mice of ages 1 to 5 days exhibits a maximum at $\mathrm{T}_{\mathrm{B}}$ s of $28^{\circ}$ to $32^{\circ} \mathrm{C}$. It has been suggested that this metabolic maximum at subnormal $\mathrm{T}_{\mathrm{B}} \mathrm{S}$ might be caused by hormonal thermoregulation mechanisms. However, it was found that young mice of ages 1 to 7 days exhibit also maximum motor activity at $\mathrm{T}_{\mathrm{A}}^{\mathrm{A}} \mathrm{s}$ of $24^{\circ}$ to $29^{\circ} \mathrm{C}$, the corresponding $\mathrm{T}_{\mathrm{B}} \mathrm{s}$ being about $25^{\circ}$ to $31^{\circ} \mathrm{C}$ (Fig. 3; LAGERSPETz 1966). A decrease 
of oxygen consumption below $28^{\circ} \mathrm{C}$, for temperatures at which motor activity is still at its maximum, can be explained as the outcome of the direct depressing effect exerted by the decreasing $\mathrm{T}_{\mathrm{B}}$ on metabolic rate.

Thus, the motor responses of young mice to temperature are in principle similar to the orthokinetic orientation mechanism (FRAENKEL \& GUNN 1940) which appears in the thermal behaviour of several poikilothermic animals (KERKUT \& TAYLOR 1958) and leads to an aggregation of the animals to a preferred temperature range. Behavioural selection of preferred temperature has been shown to occur also in young

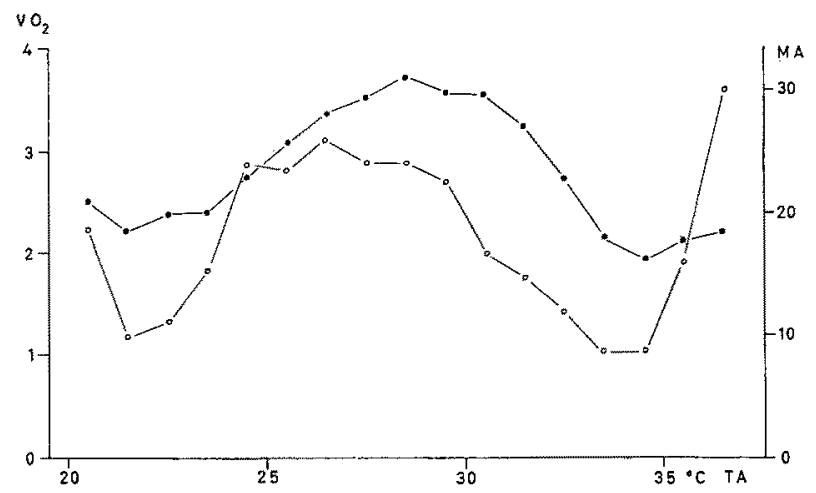

Fig. 3: Mean rate of oxygen consumption $(\mathrm{ml} / \mathrm{g} \cdot \mathrm{h}$, dots: scale to left) and mean motor activity (percentage of time spent in motion, open circles: scale to right) at different ambient temperatures in mice at ages from 1 to 7 days (After LAGERSPETZ 1965)

mice (Baccino 1935, Herter 1936). In addition to its importance in the selection of a preferred temperature range, the orthokinetic response to temperature has another, more direct, thermoregulatory function in young homoiotherms. The higher metabolic effect of increased motor activity, together with a smaller surface-to-volume ratio and better insulation, permits young homoiotherms such as mice to maintain $T_{B}$ on a somewhat higher level than $T_{A}$ over a certain range of $T_{A}$. Moreover, this effect appears at an early age. Apparently the orthokinetic response to temperature is one of the first thermoregulatory mechanisms occurring both in evolution and in ontogenetic development (LAGERSPETz 1966).

\section{THYROID AND THE CATECHOLAMINES}

SAMEL (1963) found that the relative weight of the thyroid and its 131 I-uptake are relatively low in newborn rats and increase at the end of the second week of postnatal life. A study of the histological structure of the thyroid in young mice (TARKKonen \& TIRri 1964) showed that the relative amounts of colloid and epithelium reach normal adult ratio between the ages of 10 and 15 days (Fig. 4). This change is paralleled by an increase in the succinic dehydrogenase complex activity in the liver of young mice (Fig. 5). 
Subsequent unpublished experiments by Dr. R. TIRri and Mr. M. Pantio revealed that, in rats, the activity of succinic dehydrogenase in the liver can be increased by up to $80 \%$ over control levels by repeated Na-l-thyroxine injections,

Hg red. TTC/mg. $\$ 0 \mathrm{~min}$

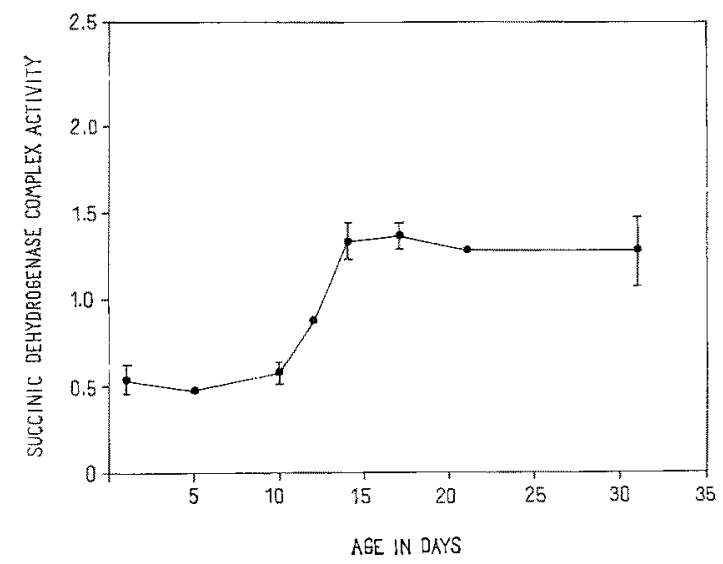

Fig. 4: Development of the succinic dehydrogenase complex activity in liver homogenates of young mice. The vertical bars indicate standard deviations. (After TARKKONEN \& TIRRI 1964)

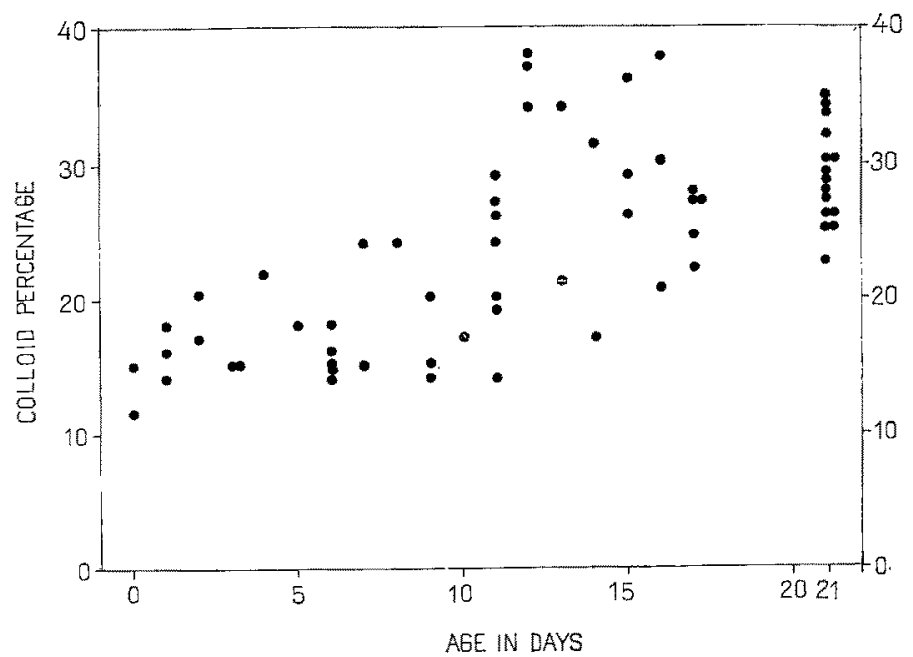

Fig. 5: Percentage of colloid in the thyroid sections from young mice as a function of their postnatal age. (After TARKKONEN \& TIRRI 1964)

if the rats are from 5 to 15 days of age. This increase in enzyme activity does not occur if the rats are 20-day-old or older at the onset of the thyroxine treatment. As thyrotropin (TSH) seems to be as effective as thyroxine in producing an increase in 
succinic dehydrogenase activity, the apparently low thyroid activity of young mice and rats probably depends on the inadequacy of TSH production.

The oxygen consumption of newborn mice seems to be remarkably insensitive to adrenaline. Figure 6 shows the mean metabolic response caused by an injection of $0.5 \mathrm{mg} \mathrm{l-adrenaline} \mathrm{per} \mathrm{kg}$ of body weight in mice of different ages (LAGERSPETZ,

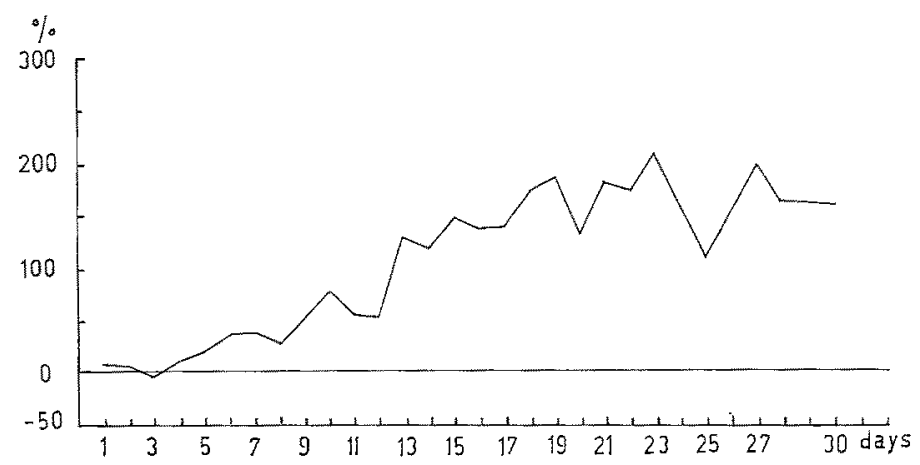

Fig. 6: Percent increase of oxygen consumption caused by subcutaneous injection of $0.5 \mathrm{mg}$ 1 -adrenaline per $\mathrm{kg}$ body weight in mice aged from 1 to 30 days. Measurements in a thermoneutral environment. (After Lagerspetz, Auvinen \& TirRi 1966)

AUVINEn \& TiRri 1966). The metabolic response to adrenaline is developed gradually between the ages of 5 and 16 to 20 days. The lack of metabolic response in newborn mice does not depend on a failure of carbohydrate mobilization caused by adrenaline. The small carbohydrate stores present in the liver and muscles of 1 to 2-day-old mice are greatly reduced by adrenaline just as the larger carbohydrate reserves of 20-day-old mice (op. cit.).

However, even young mice, 2 days of age, can be conditioned by thyroxine to respond metabolically to adrenaline. A single injection of thyroxine was sufficient to produce metabolic sensitivity to adrenaline in young mice which do not usually respond to adrenaline. An $80 \%$ increase in oxygen consumption was found to be the mean metabolic response of thyroxine-treated mice at an age of 3 days (LAGERSPETZ, AuVINEn \& TiRri 1966).

Thus, the development of thyroid activity, which occurs (probably as a result of the maturation of the hypophysis) between the ages of 10 and 15 days seems to produce an increase in tissue metabolism in the liver as indicated by an increase in the succinic dehydrogenase activity. The thyroid probably also participates in producing the metabolic responsiveness to adrenaline as well.

The function of the adrenomedullary thermoregulation mechanism described by CANNON (1932) presupposes (1) sensitivity of thermogenesis to adrenaline, (2) presence of adequate stores of adrenaline, and (3) an appropriate releasing mechanism for the stores. The first of these conditions is not fulfilled at birth in mice but is well developed at the age of 16 to 20 days. The second condition was studied by determining the catecholamine contents of adrenal excised from mice of different ages (LAGERSPETZ \& Hissa, unpublished). The aluminium oxide - trihydroxyindole proce- 
dure of Antion \& SAYRE (1962) was used, and the determinations were made with the fluorimetric technique of HÄGGENDAL (1963) using an Aminco-Bowman spectrophotofluorometer. The results, expressed as micrograms per pair of adrenals, and the animal weights are presented in Figure 7.

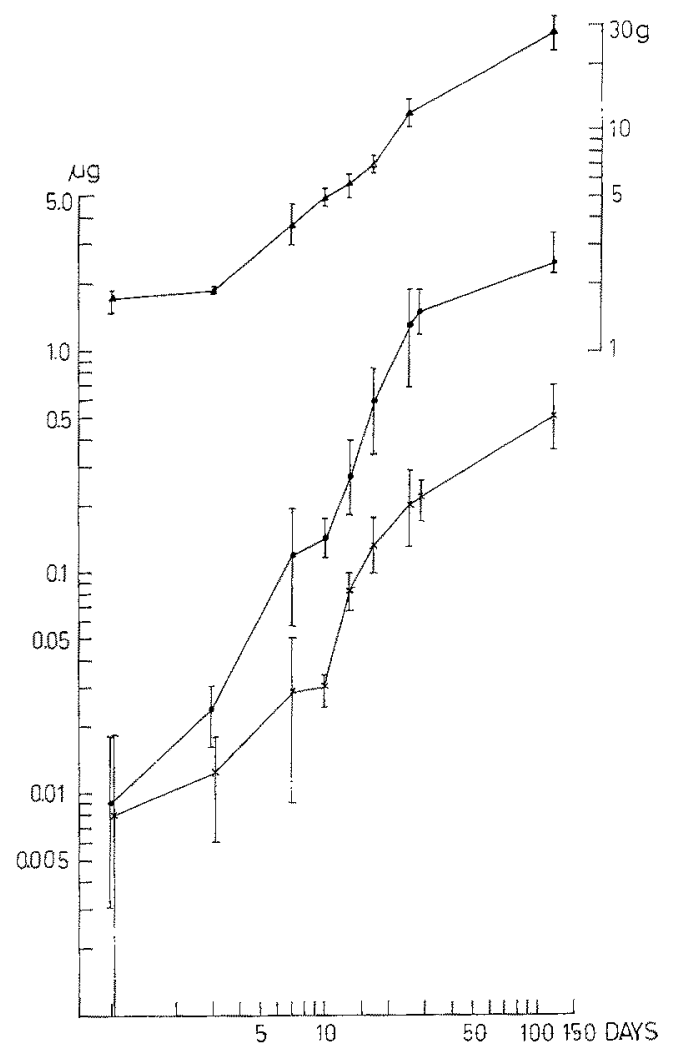

Fig. 7: Body weight (in grams, uppermost graph, scale to right), adrenaline content (in micrograms, dots, scale to left) and noradrenaline content (in micrograms, crosses, scale to left) of pairs of adrenals in mice at different age levels. Horizontal axis: postnatal age in days. Vertical bars indicate total variation ranges. All scales are logarithmic. (After LAgERspetz \& Hissa, unpublished)

The catecholamine stores in the adrenal medulla are very low in newborn mice but increase steadily as the body weight increases. Similar results for rats have been

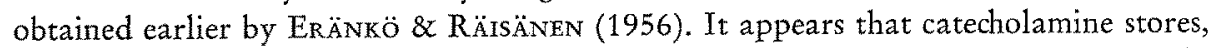
although inadequate at birth, are adequate for thermoregulation by approximately three weeks of age.

The third condition for the operation of the adrenomedullary thermoregulation mechanism is the function of an appropriate releasing mechanism. The adrenal medulla is innervated by the sympathetic nervous system through myelinated cholinergic fibers from the greater splanchnic nerve. According to WeKsTEIN (1964), the administration of sympatholytic drugs or nerve-growth-factor antiserum for the destruction of the 
sympathetic ganglia does not affect the cooling rate of 6-day-old rats but impairs the thermoregulation of rats aged 10 days, and even more profoundly in rats aged 16 days. It is probable that the sympathetic releasing mechanism for adrenomedullary catecholamines is well developed in mice by the age of $21 / 2$ weeks.

\section{MUSCLE SHIVERING}

The dependence of muscle shivering on $T_{A}$ and $T_{B}$ in young mice of different ages is at present being studied using an electronic integration and recording technique. The results obtained thus far show that muscle shivering at first appears at the age of 10 days and reaches its maximum intensity at $\mathrm{T}_{\mathrm{B}}$ of approximately $23^{\circ} \mathrm{C}$. Shivering develops to its maximal extent between the ages of 15 and 17 days. This coincides with the time of maturation of the electrocorticogram in mice, which, according to KoBAYASHI et al. (1963), occurs at the age of 15 to 17 days. This is the same age when the different layers and interneuronal connections of the motor cortex attain the pattern seen in the adult mouse (op. cit.). Thus, the development of muscle shivering probably is conditioned by the development of the motor cortex.

\section{COMPARATIVE DATA}

Length of gestation, weight at birth and mean daily growth for four species of rodents during the first two weeks of postnatal life are shown in Table 1. As indicated above, the development of thermoregulation in the rat seems in many ways to be parallel with that in the laboratory mouse, in spite of the large differences in the weight of the newborn and in their growth rate. Earlier work on the rat was summarized by ADOLPH (1957).

Hissa (1964) and Hissa \& LAGerspetz (1964) have studied the postnatal development of homoiothermy in the golden hamster (Mesocricetus auratus) and in the Norwegian lemming (Lemmus lemmus) from a comparative point of view. The development of homoiothermy in these species is described in Figures 8 and 9.

The development in the golden hamster is similar to that in the mouse (Fig. 1), except that no deviations from poikilothermy appear to occur in the golden hamster

Table 1

Data on four species of rodents used in experiments on the postnatal development of thermoregulation

\begin{tabular}{|lccc|}
\hline Species & $\begin{array}{c}\text { Gestation } \\
\text { length } \\
\text { (days) }\end{array}$ & $\begin{array}{c}\text { Mean weight } \\
\text { at birth } \\
(\mathrm{g})\end{array}$ & $\begin{array}{c}\text { Mean daily } \\
\text { growth; 2 weeks } \\
\text { (g/day) }\end{array}$ \\
\hline Mouse & $19-20$ & 1.4 & 0.5 \\
Rat & $20-21$ & 4.0 & 1.6 \\
Golden hamster & $16-17$ & 2.0 & 0.8 \\
Norwegian lemming & $20-21$ & 3.9 & 1.0 \\
\hline
\end{tabular}




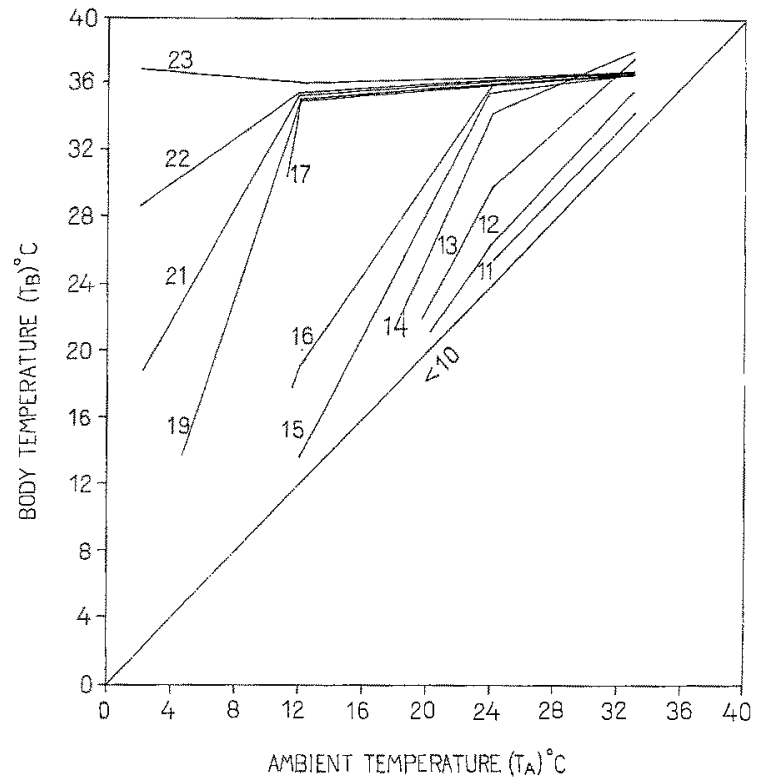

Fig. 8: Stabilized body temperature of golden hamsters at different ages as a function of ambient temperature. Age in days on each curve. (After Hissa \& LAGERSPETZ 1964)

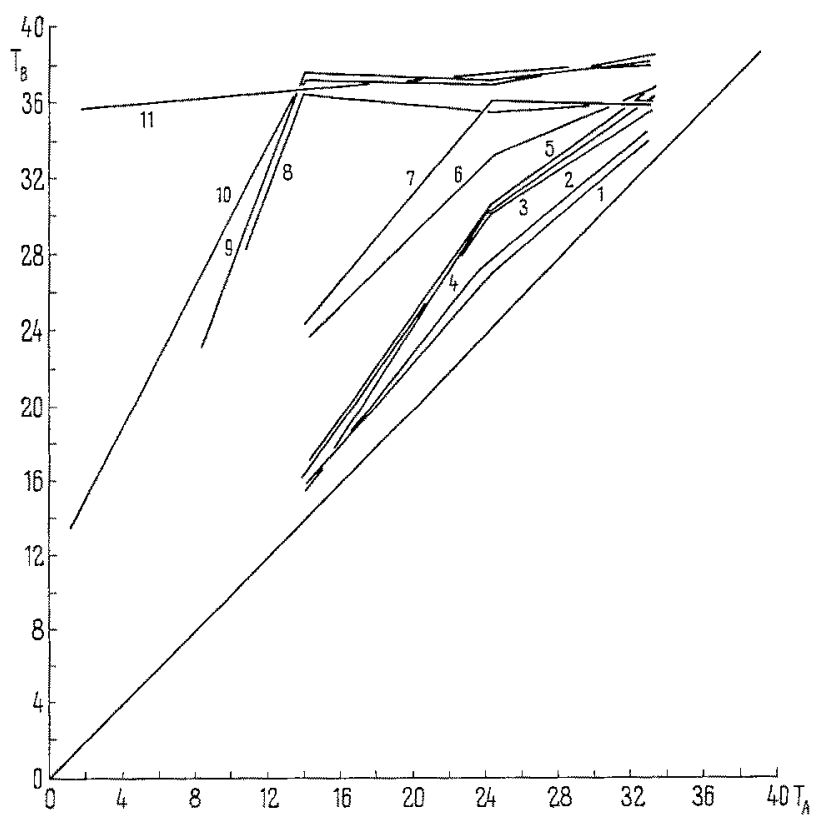

Fig. 9: Stabilized body temperature (vertical axis) of Norwegian lemmings at different ages as a function of ambient temperature (horizontal axis). Age in days on each curve. (After Hissa 1964) 
before the age of 11 days. The thermoregulatory mechanisms which operate in newborn mice (i. e. behavioural thermoregulation by thermo-orthokinesis, as well as mechanisms depending on the adrenal cortex and brown fat) seem to be ineffective in young golden hamsters. The Norwegian lemming displays a quite different type of development. In this species, homoiothermy develops rapidly atter birth. This depends partially on the high metabolic activity of the tissues of newborn lemmings, which is indicated, e. g.

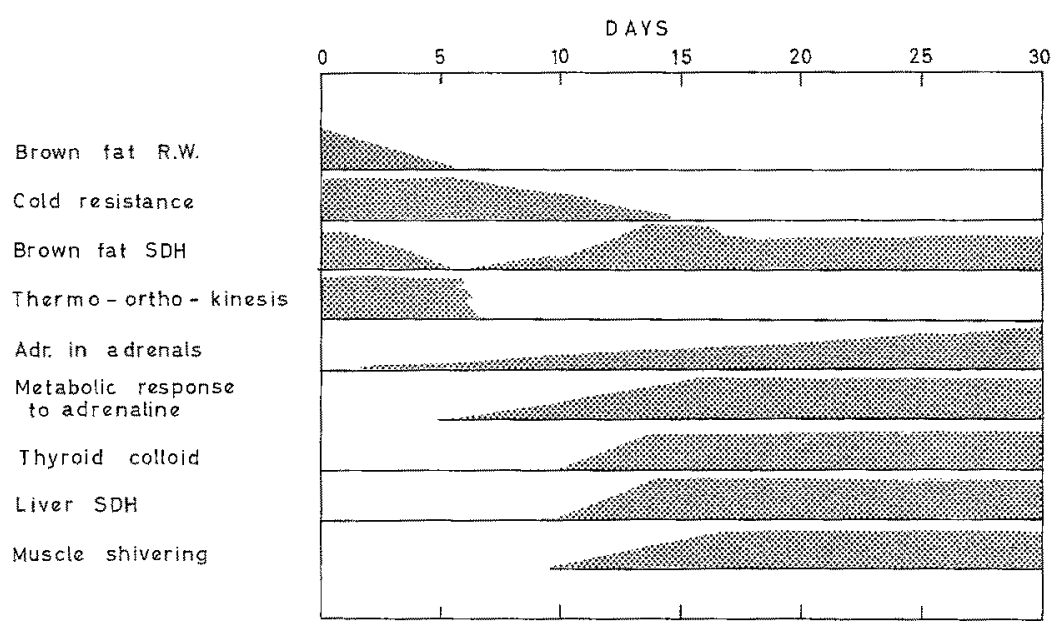

Fig. 10: The approximate changes in the different variables studied in young mice as a function of age. Horizontal axis: age in days. R. W.: relative weight, SDH: succinic dehydrogenase activity

by the high succinic dehydrogenase activity measured from liver homogenates of 1-day-old lemmings (Hrssa, unpublished observations). In addition, muscle shivering in lemmings also develops earlier than in golden hamsters and mice (Hissa 1964). Definite shivering was recorded from lemmings at only 7 days of age.

The subarctic Norwegian lemming thus shows a rapid development of thermoregulation and in this respect is intermediate between other small rodents and larger ones (e. g. the guinea pig) which already have a rather well-developed thermoregulation at birth.

\section{GENERAL CONCLUSIONS}

The main results obtained in the study of the postnatal development of thermoregulation in laboratory mice are summarized in Figure 10. To this date experimentation has been concentrated on the development of thermogenetic mechanisms, while virtually no attention has been paid to the development of vasomotorics, thermal conductivity and insulation. It is believed that the maturation of the central nervous system and the subsequent activation of endocrines are the main factors responsible for the development of thermogenesis. The developmental approach seems to be a suitable method for the analysis of complex cybernetic systems in living organisms. 


\section{SUMMARY}

1. Laboratory mice exhibit nearly complete poikilothermia up to 7 days after birth. This period is characterized by high cold resistance, high relative weight and succinic dehydrogenase activity of the brown fat and thermo-orthokinesis. It is possible that the adrenal cortex already at this age also participates in thermoregulation.

2. Increase in the heat production between ages of 7 and 15 days, which allows for homoiothermy at ambient temperatures of $20^{\circ}$ to $30^{\circ} \mathrm{C}$, is accompanied with an increase in the succinic dehydrogenase activity in the liver. This is probably caused by the increase in the thyroid activity which also makes the oxygen consumption sensitive to adrenaline.

3. Muscle shivering reaches the adult level at the age of 15 to 17 days.

4. Catecholamine stores in the adrenal medulla increase steadily during the growth. It is probably that the conditions for adrenomedullary thermoregulation attain the functional level found in adults at the age of about three weeks.

5. Comparative data on the golden hamster and on the Norwegian lemming are presented.

6. Maturation of the central nervous system and subsequent activation of the endocrines are probably the main factors responsible for the development of thermogenesis.

7. The developmental approach seems to be a suitable method for the analysis of complex cybernetic systems in higher animals.

\section{ACKNOWLEDGEMENTS}

The following students at the Zoophysiological Laboratory, Department of Zoology, University of Turku, have participated in the work reported here: Miss L. Auvinen, M. Sc., Mr. R. Hissa, M. Sc., Miss H. Julku, Mr. M. Pantio, Mr. H. TarkKonen, M. Sc., and Mr. R. Trrri, Ph. D. The technical assistance of Miss H. Kurppa and Mrs. S. Hirlgren is gratefully acknowledged. The experimental work has been financially supported by the National Science Council of Finland (Valtion Luonnontieteellinen Toimikunta).

\section{LITERATURE CITED}

Adolph, E. F., 1957. Ontogeny of physiological regulations in the rat. Q. Rev. Biol. 32, $89-137$.

Anton, A. H. \& Sayre, D. F., 1962. A study of the factors affecting the aluminum oxide trihydroxyindole procedure for the analysis of catecholamines. J. Pharmac. exp. Ther. 138, $360-375$.

Baccino, M., 1935. La température optimum de croissance des jeunes homéothermes. Diverses méthodes de détermination. C. $r$. Séanc. Soc. Biol. 119, 1246-1248.

BaLL, E. G. \& JunGAS, R. L., 1961. On the action of hormones which accelerate the rate of oxygen consumption and fatty acid release in rat adipose tissue in vitro. Proc. natn. Acad. Sci. U.S.A. 47, 932-941. 
Cassin, S., 1963. Critical oxygen tensions in newborn, young, and adult mice. Am. J. Physiol. 205, 325-330.

Dawkins, M. J. R. \& Hull, D., 1964. Brown adipose tissue and the response of new-born rabbits to cold. J. Physiol., Lond. 172, 216-238.

ERÄNKÖ, O. \& RÄISÄNEN, LIISA, 1956. Adrenaline and noradrenaline in the adrenal medulla during postnatal development of the rat. Endocrinology 60, 753-760.

Fraenkel, G. S. \& Gunn, D. L., 1940. The orientation of animals. Univ. pr., Oxford, 352 pp.

HaHN, P. \& KoldovskÝ, O., 1958. Significance of the adrenal glands during the post-natal development of thermoregulation in the rat. Nature, Lond. $181,847$.

Herter, K., 1936. Das thermotaktische Optimum bei Nagetieren, ein mendelndes Art- und Rassenmerkmal. Z. vergl. Physiol. 23, 605-650.

Hrssa, R., 1964. The postnatal development of homoiothermy in the Norwegian lemming (Lemmus lemmus). Experientia 20, 326-327.

- \& LAgERsPeTz, K., 1964. The postnatal development of homoiothermy in the golden hamster. Annls Med. exp. Biol. Fenn. 42, 43-45.

HäGGENDAL, J., 1963. An improved method for fluorimetric determination of small amounts of adrenaline and noradrenaline in plasma and tissues. Acta physiol. scand. 59, 242-254.

KERKUT, G. A. \& TAYror, B. J. R., 1958. The effect of temperature on the activity of poikilotherms. Behaviour 13, 259-279.

Kobayashi, T., Inman, O. R., Buno, W. \& Hrmwich, H. E., 1963. A multidisciplinary study of changes in mouse brain with age. Recent Adv. Biol. Psychiatry 5, 293-308.

Kun, E. \& Azood, L. G., 1949. Colorimetric estimation of succinic dehydrogenase by triphenyltetrazolium chloride. Science, N.Y. 109, 144-146.

LAGERSPETZ, K., 1962. The postnatal development of homoiothermy and cold resistance in mice. Experientia 18, 282-284.

- 1966. Temperature relations of oxygen consumption and motor activity in newborn mice. Annls Med. exp. Biol. Fenn. 44, 71-73.

- Auvinen, L. \& TirRI, R., 1966. The postnatal development of the metabolic response to adrenaline in mice. Annls Med. exp. Biol. Fenn. 44, 67-70.

- Tarkkonen, H. \& Tirri, R., 1962. Effect of cold acclimatization on the succinic dehydrogenase activity in the liver and brain tissues of mice. Experientia 18, 552.

PтснотKA, J., 1960. Die Beziehung zwischen Körpertemperatur und Stoff wechselgröße bei neugeborenen Nagern. Pfï̈gers Arch. ges. Physiol. 272, 26.

- 1964. Chemische Temperaturregulation bei neugeborenen Mäusen. Helgoländer wiss. Meeresunters. 9, 274-284.

SAmEL, M., 1963. Thyroidal $I^{131}$ uptake during postnatal ontogenesis in rats. Proc. 16th Int. Congr. Zool. 2, 155.

Sмiтh, R. E., 1963. Discussion in Symposium on temperature acclimation. Fedn Proc. Fedn Am. Socs. exp. Biol. 22, 822-823.

Tarkxonen, H. \& TrRrr, R., 1964. Thyroid development and succinic dehydrogenase activity in the liver of young mice. Annls Med. exp. Biol. Fenn. 42, 82-84.

WeKstein, D. R,, 1964. Sympathetic function and development of temperature regulation. Am. J. Physiol. 206, 823-826. 